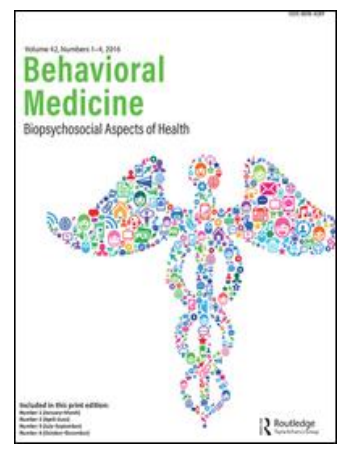

Behavioral Medicine

ISSN: 0896-4289 (Print) 1940-4026 (Online) Journal homepage: http://www.tandfonline.com/loi/vbmd20

\title{
Problematic gaming behavior among Finnish junior high school students: Relation to socio-demographics and gaming behavior characteristics
}

Niko Männikkö, Heidi Ruotsalainen, Zsolt Demetrovics, Olatz LopezFernandez, Laura Myllymäki, Jouko Miettunen \& Maria Kääriäinen

To cite this article: Niko Männikkö, Heidi Ruotsalainen, Zsolt Demetrovics, Olatz LopezFernandez, Laura Myllymäki, Jouko Miettunen \& Maria Kääriäinen (2017): Problematic gaming behavior among Finnish junior high school students: Relation to socio-demographics and gaming behavior characteristics, Behavioral Medicine, DOI: 10.1080/08964289.2017.1378608

To link to this article: http://dx.doi.org/10.1080/08964289.2017.1378608

Accepted author version posted online: 14 Sep 2017.

Submit your article to this journal $₫$

Q View related articles ¿

View Crossmark data \lceil 


\section{Problematic gaming behavior among Finnish junior high school students: Relation to socio-demographics and gaming behavior characteristics}

Niko Männikkö ${ }^{1,2,}$, Heidi Ruotsalainen ${ }^{1}$, Zsolt Demetrovics ${ }^{3}$, Olatz Lopez-Fernandez ${ }^{4,5}$, Laura Myllymäki ${ }^{1}$, Jouko Miettunen ${ }^{1,6}$, Maria Kääriäinen ${ }^{1,6}$

${ }^{1}$ University of Oulu, Finland

${ }^{2}$ Oulu University of Applied Sciences, Finland

${ }^{3}$ Eötvös Loránd University, Hungary

${ }^{4}$ Nottingham Trent University, United Kingdom

${ }^{5}$ Université catholique de Louvain, Belgium

${ }^{6}$ Oulu University Hospital, Finland

"Corresponding author: Niko Männikkö, email. niko.mannikko@oamk.fi, Kiviharjuntie 4, 90220 Oulu, Finland

"Compliance with Ethical Standards"

Multi-platform digital media use and gaming have been increased in recent years. The aim of this study was to examine associations between socio-demographics and digital gaming behavior characteristics (i.e., gaming time, medium, and genres) with problematic gaming behavior in adolescents. A convenience sample of Finnish junior high school students ( $n=560$; mean age 14 years, ranging from 12 to 16 years) participated in the cross-sectional survey, of which, $83 \%(n=465)$ reported having played digital games regularly. Socio-demographic data, different forms of digital media use, gaming behavior characteristics and problematic gaming behavior was assessed. Study participants spent on average one hour per day playing digital games; casual games (23.9\%), shooting games (19.8\%), and sport games (12.9\%), were the most popular games among participants. By using regression analysis, a blended family structure and gaming time related positively to problematic gaming behavior. Preferences for game 


\section{ACCEPTED MANUSCRIPT}

genres such as solo, Massively Multiplayer Online Role-Playing and strategy-management games were also positively associated with problematic use of digital games. These findings provide knowledge that can be utilized in the prevention of the possible negative consequences of digital gaming.

Keywords

Internet Gaming Disorder; problematic gaming; digital media use; adolescents; gaming types 


\section{ACCEPTED MANUSCRIPT}

\section{INTRODUCTION}

Young people are increasingly adopting digital media. According to several recent reports, young people in developed countries spend an increasing amount of time engaged in various digital and online activities ${ }^{1-5}$. Over the past decade, gaming has become one of the main online activities among adolescents and at the same time this activity has partly moved on from being computer (PC) or console-based towards being a multi-platform activity ${ }^{6}$. Consequently, mobile games are one of the most heavily adopted entertainment sectors of the multi-media application industry in Europe $^{7}$. For instance, statistics on gaming in Finland have shown that in 2015, over half of the individuals (52\%) in age groups under 20 years have reported playing digital games daily and most of these people ( $88 \%$ ) have played games actively using mobile phones ${ }^{8}$. In this context the use of modern media and gaming technologies has emerged into behavior patterns that have become increasingly ubiquitous in individuals' everyday lives.

Even though a light to moderate level of digital connectivity on a daily basis, including light engagement with gaming, may be advantageous for some adolescents $^{9,10}$, for others it may lead to excessive use and dependence-like problems ${ }^{11-12}$. The previous studies examining excessive gaming and its related problematic outcomes have mainly adapted assessment tools based on generalized Internet, pathological gambling or specific video gaming criteria ${ }^{11,13}$. Recently, Internet Gaming Disorder (IGD) has been recognized as a potential disorder listed in Section 3 of the latest version of the Diagnostic and Statistical Manual for Mental 


\section{ACCEPTED MANUSCRIPT}

Disorders, 5th Edition (DSM- $5^{14}$ ). However, researchers in the field have found deficiencies encompassing the base criteria (i.e., components of substance use disorder criteria) and theory behind the IGD model ${ }^{15-17}$, and thus a congruent basis of assessment practices has not been agreed ${ }^{18}$. In the current study, Problematic Gaming Behavior (PGB) was adapted when referring to the condition under problematic involvement with digital games because of the incompleteness and unofficial status of the IGD.

Numerous studies have highlighted potential factors affecting the interrelations between the problematic use of games and harmful outcomes including demographic factors, such as gender ${ }^{19}$, age ${ }^{20}$, education status ${ }^{21}$, as well as individual factors, such as personality ${ }^{22-23}$, and self-esteem ${ }^{24}$, and social related factors, such as loneliness ${ }^{24-25}$ or general social functioning ${ }^{26-27}$. Furthermore, although several studies have investigated the relationship between family functioning and excessive engagement in gaming $^{27-29}$, to date, no research has examined the interdependence between adolescents' family structure and PGB.

Digital games can be split into two main categories based on their Internet integration, namely online and offline digital games. Online games are used via the Internet or other computer network and they typically include social features where players can interact with other users in a common and persistent virtual environment ${ }^{30}$, whereas offline games are typically played individually and it do not require an Internet connection. Among the most popular game genres, Multiplayer Online Role-Playing Games (MMORPG) have especially been linked to PGB ${ }^{31,11}$. 


\section{ACCEPTED MANUSCRIPT}

However, relationships between offline or online gaming and PGB have not always been clear, and evidence on outcomes has been mixed due to complexity in the interaction between different game medium and genres ${ }^{32}$. In addition, the game type characteristics of role-playing ${ }^{33-35}$, strategy ${ }^{34}$ and shooting ${ }^{33,35}$ games have been linked to a proneness to PGB symptoms. On the other hand, it has also been shown that the high use of many digital game types can be associated with PGB potential ${ }^{36}$. Given these findings, it is expected that a preference for game genres relating characteristics of role-playing, strategy and shooting will be positively associated with PGB (Hypothesis 1), however, there is a lack of evidence showing interrelating links between computer gaming, mobile gaming (i.e., mobile/smartphones and tablets) and game genre variables.

Because many online activities occur simultaneously and include complex interactions, it is not easy to point out the exact role of these distinct activities in problematic behavior ${ }^{37}$. Although digital gaming behavior related detrimental outcomes have been considered to be more linked to qualitative than quantitative factors $^{38-39}$, the association between overall screen time consumption with behavioural and health outcomes has received increased attention among scholars ${ }^{40}$. Moreover, excessive consumption of various digital media seems to predict a greater probability that the users experience negative health consequences evolving later in life $e^{40-42}$. Thus, around two hours of daily screen time consumption has been typically advocated for children and adolescents ${ }^{43-44}$, however, this recommendation was later excluded from their new advice due to the media landscape change ${ }^{45}$. To alleviate 


\section{ACCEPTED MANUSCRIPT}

possible evolving problems, researchers have suggested that the total screen time should be harmonized with other activities, such as socializing, physical activity and reading ${ }^{46}$. Against this evidence background, it is particularly relevant to increase knowledge basis, including qualitative and quantitative factors of how adolescents use various digital media given the prompt technological advancement described in recent years ${ }^{47}$.

In regard to the global phenomenon of digital gaming, there is scarce empirical evidence today relating to role of different forms of digital media specifically, the modern use of digital technology, facilitating potential PGB. Overall, it is necessary to enhance our knowledge about patterns of use and interactions of digital gaming behavior and different digital media tools (i.e., potential cross-platform associations or multiplatform usage) within various age groups. The aim of this study is to investigate the association between socio-demographic factors, digital gaming behavior characteristics (i.e., gaming time, medium and genres) and self-reported PGB symptoms. Based on previous research, the following hypothesis is formulated: It is expected that games, including role-playing, strategy and shooting elements, will be related to elevated PGB symptoms. Furthermore, the present study considers the conjoined function of gaming medium (i.e., PC gaming and mobile gaming) and genres in multivariate analysis to make a unique contribution to this area of research. Thus, the purpose is also to describe the quantitative role of digital gaming in relation to other media activities on a daily basis. 


\section{ACCEPTED MANUSCRIPT}

\section{METHODS}

Sample and procedure

Data were collected in two junior high schools, each having similar socio-economic characteristics, in northern Finland in the fall of 2015. A pilot study was carried out ( $n=17)$ to ensure the feasibility of an online survey (e.g., relevance and clarity of the questions, time duration needed for the answering). The study population consisted of 846 students from the 7 th to 9 th grades ${ }^{1}$. An anonymous self-completion webbased questionnaire was administered to students during class time. Once students entered to the survey website, they had access to the instructions. Due to refusal or absence at the time of data-gathering $(n=283)$, inconsistent or incomplete answers $(n=3)$, the sample database consisted of 560 participants. The analytical part was carried out on the subsample of participants who had played digital games regularly (i.e., exclusion of 95 non-gamers) during the last three months including 465 participants (173 girls and 292 boys).

The study was conducted in accordance with the Declaration of Helsinki. The school administrators gave their permission to conduct the study. Parents were informed about the study in advance and they had the opportunity to decide whether they wanted to their child(ren) to participate in the study or not. All participants provided informed consent prior to participation in the study. No identification information

\footnotetext{
${ }^{1}$ In Finland, 7th to 9th grades consist of the first, second and third year of the junior high school that is intermediate between elementary school and senior high school. Students in these grades are usually 12-16 years old.
} 


\section{ACCEPTED MANUSCRIPT}

(e.g., Internet Protocol [IP] address) was collected. Participation in the survey was voluntary and anonymous.

Measures

The survey consisted of two sections: a) socio-demographic data, and information on digital media use (i.e., background variables) and b) digital gaming behavior characteristics, and questions regarding problematic gaming behavior.

The socio-demographic section included variables on gender, age, school grade, and family status (nuclear family, shared physical custody, single-parent household, blended family, other).

The digital media use section was extracted from the Tech Use Disorders (TUD) research project survey ${ }^{48}$ and consisted of the following variables: possession of a mobile/smartphone with Internet access or without Internet access, ownership of a tablet or personal computer, the average duration (minutes) per day spent using different media devices, such as a personal computer, tablet, mobile/smartphone (outside activities related work/study) on a typical weekday and weekend day. Based on this media usage data, which was consistent with previous methods ${ }^{49}$ an "average daily use" variable was generated for each media activity [(week day $\bullet 5)+($ weekend day $\bullet 2)] / 7$.

To assess digital gaming characteristics, participants were asked to report the average duration in minutes they spent playing digital games on a typical day and in a typical week. In addition, participants were asked to select game genres they had played 


\section{ACCEPTED MANUSCRIPT}

most frequently in the last twelve months, comprised following options: Casual Games (e.g., Candy Crush, Farmville, Angry Birds), Solo Video Games (par ex., Grand Theft Auto, Monkey Island, Chaos Ring), Vehicle Simulation Games (e.g., Farming Simulator 14, Aerofly 2, Flight Simulator), Strategy and Management Games (e.g., The Sims, Plant VS Zombies, Clash of Clans), Sport Games (e.g., FIFA 15, True Skate, Asphalt), Shooting Games Online or "First Person Shooters" [FPS] (e.g., Call of duty: Black Ops Zombies, Sniper 3D Assassin: shoot to kill), Multiplayer Online Battle Arenas [MOBA] (e.g., Heroes of Order \& Chaos, Vainglory), or Massively Multiplayer Online Role-Playing Games [MMORPG] (e.g., Order \& Chaos Online, Dawn of the Immortals). Additionally, participants were asked to report whether the selected game genres they played the most also involved offline gaming (including the answer categories: yes, no and I do not play offline games).

Problematic gaming behavior was measured by the Problematic Online Gaming Questionnaire (POGQ), which measures six dimensions of problematic gaming, which are: a preoccupation with games, withdrawal symptoms, overuse regarding the amount of gaming, immersion, social isolation and interpersonal conflict ${ }^{50}$. The scale contains 18 items rated on a 5-point Likert ordinal scale from 1 "never" to 5 "always". A cut-off of 66 points serves as a basis for identifying problematic use ${ }^{50}$. The Cronbach's alpha of the POGQ was .93 in the current study. The Finnish version of the scale had been produced by using a translation/back-translation procedure supported by researchers and a linguistic expert translator ${ }^{51}$. Two Finnish researchers 


\section{ACCEPTED MANUSCRIPT}

translated the original English version of the scale independently and then it was back-translated into the original language by an external researcher. The final version was assessed based on comparison and a consensus was reached on these versions. The structural validity of the translated POGQ scale was tested by achieving acceptable fit model indices from confirmatory factor analysis (CFA). Results of CFA with maximum likelihood was based on root mean square error of approximation $(\mathrm{RMSEA}=.07)$, comparative fit index $(\mathrm{CFI}=.93)$ and Tucker-Lewis index $(\mathrm{TLI}=.91)$. The POGQ scale with its six dimensions also indicated acceptable inter-related correlates ranging from .49 to .88 . Moreover, the Cronbach's alpha coefficients with values ranging between .66 and .86 showed adequate inter-item association across subscales ${ }^{52}$. The factor correlations and internal consistencies are presented in Table 1.

Statistical analysis

Statistical differences between digital game players and non-gamers were analyzed with the Chi-Square analysis and independent t-test. Statistical differences between socio-demographic variables were analyzed with the Mann-Whitney's U test and with Kruskal Wallis test in cases of more than two groups. The inter-item association for POGQ subscales was determined using Cronbach's alpha ${ }^{52}$. In addition, Pearson correlation coefficients were used to examine associations between the POGQ total score and average use of different media forms. The Kruskal-Wallis test was also used to analyze differences in the POGQ scores and PC and mobile device consumption for different game genres, and levels of online and offline gaming 


\section{ACCEPTED MANUSCRIPT}

preferences. Mann-Whitney $(U)$ analysis was conducted to determine whether PGB (i.e., POGQ scores) was influenced by specific game genre preferences (i.e., other game genres constituted as a reference category).

Finally, a multiple linear regression analysis was employed with the POGQ score as a dependent variable. A step-forward method was used to identify potential independent factors related to PGB. Demographic variables (sex, family structure and school grades), most popular game genre played, the average daily gaming duration and the average daily duration spent on computer, tablet and mobile or smartphone, were entered into the regression analysis. Sex, family structure, school grade and game genre were dummy coded and the first group of each section (i.e., female, the nuclear family, school grade 7 and the casual game) comprised the reference category. A preliminary check confirmed that there were no problems of multicollinearity (the variance inflation factor [VIF $<5]$ and the tolerance score for predictors [Tolerance > .20]), homoscedasticity (The Durbin-Watson coefficients) or assumptions of normality. The data analysis was performed using IBM SPSS statistics Version 22 for Windows (IBM, Chicago, IL, USA). The level of significance was set at $p<0.05$.

\section{RESULTS}

Descriptive statistics

Slightly more than half of the game player participants were male $(62.8 \%)$ and the mean age of the sample was 14 (Table 2). Of all the students, $43 \%$ were in the 


\section{ACCEPTED MANUSCRIPT}

seventh, $24.5 \%$ in eighth, and $32.5 \%$ in the ninth school grades. The majority of the respondents lived in a nuclear family $(72.3 \%)$. The students estimated that they spent more than 1 hour (minutes: $M=72.07 ; S D=111.33$ ) using a personal computer, almost half an hour (minutes: $M=27.27 ; S D=65.93$ ) using a tablet, and more than 2 hours (minutes: $M=123.15 ; S D=117.27$ ) using cell- or smartphones on a typical day. The time duration used for computer and cell- or smartphones increased gradually between each grade, whereas the time used for tablets decreased among gamers (Figure 1).

Digital gaming

Study participants spent more than an average of 1 hour $(M=74.85 ; S D=96.71)$ on gaming on a typical day. The most popular video game types were Casual Games 23.9\%, followed by Shooting Games 19.8\%, Sport Games, 12.9\%, MOBA games 5.8\%, Solo Video Games 5.2\%, Vehicle Simulation Games 4.5\%, MMORPG 3.9\%, Strategy and Management Games 3\% and other games $13.8 \%$ respectively. The average duration of daily digital gaming was highest in the group of eighth grades students (86.14 minutes, $n=114)$ and it decreased slightly compared to the participants from the ninth grade (average time was $80.84[n=150]$ ). Daily gaming time was the lowest among the survey participants from the seventh grade $(M=$ 63.92 minutes, $n=200)$.

$34.8 \%(n=162)$ of the participants reported that they did not play offline games at all, while 54.4\% $(n=253)$ expressed that their answers to the gaming behavior 


\section{ACCEPTED MANUSCRIPT}

questions were also valid for offline games as well. A mean rank of POGQ scores were significantly higher among gamers who had played both game types (with a mean rank 252, Median =28) compared to the gamers who had played only online games (with a mean rank of 185, Median $=24.5)(U=14580, p<.001)$. However, in this group comparison, gamers who expressed their gaming behavior answers (i.e., the POGQ scale) considered only Internet based online gaming and not offline gaming had the highest levels of PGB (with a mean rank of 289, Median =31).

Differences in gaming and PGB according to demographics

The average time used for gaming on a typical day differed significantly between the genders (with a mean rank of 284 [Median $=60$ ] boys versus 144 [Median $=15$ ] girls, $U=9950, p<.001$ ). The POGQ scores were significantly greater among boys than girls (with a mean rank of 263 [Median $=29]$ boys versus 182 [Median $=24$ ] girls, $U=16453, p<.001)$. POGQ scores differed also between the school grades, with a mean rank of 246 [Median $=28]$ for the seventh grade, $261[$ Median $=29]$ for the eighth grade, and 193 [Median = 24] for the ninth grade. A post-hoc comparison test indicated that adolescents in the eighth grade had significantly higher POGQ scores than survey participants in the ninth grade $(U=6099, p<.001)$. However, the average time used for digital game playing per typical day did not differ significantly between the different school grades. A group comparison of the differences in time spent on digital gaming on a typical day between different family categories showed that engagement in digital game playing (with a mean rank of 220 [Median $=30$ ] for nuclear family, 289 [Median = 60] for joint physical custody, 261 [Median $=60$ ] for 


\section{ACCEPTED MANUSCRIPT}

single-parent household, $222[$ Median $=30]$ for blended family and $216[$ Median $=$ 30] for other family structure) was significantly higher among those adolescents living in joint physical custody $(\chi 2(4)=15.32, p=.004)$. The POGQ scores were in the highest level among participants lived in the blended family structure (Median $=$ 28) whereas the level of problematic behavior symptoms was lowest in the group of the single (Median $=25)$ and nuclear (Median $=27)$ family structure. However, the differences in POGQ scores between family categories were not significant.

Differences in PGB and quantitative digital gaming and media use characteristics according to the most popular game genres among participants

Table 3 presents results of the comparison of the POGQ scores, average daily time used for gaming, computer, tablet and mobile phone or smartphone by most-used game genres. Specific genre preferences were associated ${ }^{2}$ with increased levels of PGB, namely MMORPG $(U=1855, p<.01)$, MOBA $(U=3408, p<.05)$, shooting $(U=$ 9607, $p<.01)$ and strategy-management $(U=1619, p<.05)$. On the contrary, PGB indicating scores were in the lowest level among players who preferred to use the game category of casual $(U=8491, \mathrm{p}<.001)$. Participants who preferred to play game genres of MOBA, shooting and MMORPG reported the highest level of average daily gaming time. Furthermore, the average daily amount of computer use was in the highest level among the participants who preferred to use the game categories of MOBA $(U=2285, p<.001)$ and shooting $(U=7822, p<.001)$. The average daily consumption of mobile or smartphone use was in the highest level among the

\footnotetext{
${ }^{2}$ In the pairwise comparison, other genres than as in point of question comprised the reference category
} 


\section{ACCEPTED MANUSCRIPT}

participants who preferred to use the game category of casual and shooting. Consequently, daily tablet use was exclusively high level among participants who reported the shooting games $(U=10657, p<.05)$ as the most popular game genre. On contrary, tablet use time was significantly lower level among participants who reported the MOBA $(U=3536, \mathrm{p}<.05)$ as the most popular game genre.

Correlates and the prediction model for problematic gaming behavior

The POGQ scores were positively correlated with daily gaming time $(r=.46, p<$ $.01)$, computer use $(r=.27, p<.01)$, tablet use $(r=.04$, not significant $)$, mobile or smartphone use $(r=.05$, not significant) and total media use subscales ([i.e., sum scale, consist of time used for computer, tablet and mobile phone or smartphone] $r=$ $.20, p<.01)$. Multiple linear regression analysis indicated that the variance inflation factor (VIF) and tolerance index ensured that there was not a problem of multicollinearity (i.e., $\mathrm{VIF}_{\max }=1.01$ and tolerance $\min =0.98$ ). The Durbin-Watson coefficient (i.e., 1.98) showed the absence of autocorrelation between adjacent residuals. Overall, the independent variables explained by the final model as a whole accounted for $27.7 \%$ of the variance $\left[R^{2}=.277 ; F_{(6,353)}=22.49, p<.001\right]$. Daily gaming time $(\beta=.44, p<.001)$, blended family structure $(\beta=.10, p<.05)$ and preference for game genre use of solo $(\beta=12, \mathrm{p}<.01)$, MMORPG $(\beta=.12, p<.01)$, and strategy-management $(\beta=.10, p<.05)$ were positively associated with POGQ scores. In contrast, the school grade $9(\beta=-.17, p<.001)$ was negatively associated with POGQ scores (Table 4). 


\section{ACCEPTED MANUSCRIPT}

\section{DISCUSSION}

The aims of the present study were to examine associations between sociodemographic factors, digital gaming behavior characteristics (i.e., gaming time, medium and genres) and perceived problematic gaming behavior in a sample of Finnish junior high school students. Taking the outcomes as a whole, the results demonstrated that specific socio-demographic and digital gaming behavior patterns are associated with perceived PGB symptoms. Evidence from previous research showed that online gaming especially relates to $\mathrm{PGB}^{35,53}$, but to date, there is no evidence that has addressed where both the game (content) and the medium as situation-specific feature might facilitate PGB symptoms in an integrative way.

In the present study, male gamers were more likely to display elevated PGB

symptoms than female gamers, which is consistent with previous evidence ${ }^{54}$. The results from an examination of gaming patterns in different junior high school grades showed that there were not significant differences in comparison of average duration spent on digital gaming on a typical day. However, the PGB indicating scores decreased significantly in the ninth grade.

To the authors' knowledge, this is the first study which has found that PGB is significantly-associated with blended family structures of the study participants. PGB symptoms were highest among the adolescents who lived in the blended family structure whereas the level of problematic behavior was lowest in the group of the single and nuclear family structure. Moreover, adolescents having lived in blended or 


\section{ACCEPTED MANUSCRIPT}

shared physical custody or single family structures spent more time on digital gaming than the adolescents living in a nuclear family structure did. One plausible explanation for this difference is that problematic involvement in gaming could be partly related to maladaptive coping mechanism through escapism motivations ${ }^{55}$, arguably especially relating to the situation of unbalanced family cohesion ${ }^{56}$ or where parents spend different amounts of time with their children. More specifically, these gamers might have intentionally engaged in gaming as a means to relieve or regulate feelings of discomfort associated with life alteration (i.e., also considered a theoretical view of self-mediation ${ }^{57}$ ). The present findings highlight that the family structure may also be related to the risk of PGB symptoms among younger gamers, and further examination is required to elucidate the connection and its underlying mechanisms.

To date, there have been scarcely any studies that have shown the importance of different media device use (as a channel for gaming content) in relation to PGB symptoms. Although different media devices, especially computers, were highly used, the results of the present study did not show an explicit link between certain gaming medium and PGB. This finding could be congruent with the view that gaming with multiple-medium and gaming behavior is ubiquitous among adolescents. Furthermore, although adolescents can perform one or more activities with PC and mobile devices (e.g., social networking and video viewing), gaming behavior constitutes a big role in daily technology activities and thus also for the total 


\section{ACCEPTED MANUSCRIPT}

screen time. More specifically, the relative proportion of gaming time from the total consumption of PC and mobile device use varied from $15 \%$ to $50 \%$.

It is worth noting that mobile devices (i.e., usage rate of smartphones and tablets for digital game playing reported to be $37 \%$ among the Finnish population) have overtaken all other patterns of digital game playing, including computer games and console video games in Finland ${ }^{8}$. However, to the best of the authors' knowledge, in general only scarce previous studies have shown the problematic behavior potential of smartphone gaming ${ }^{58}$.

Tablets have been used to a greater extent for entertainment purposes, such as video viewing, gaming and music, especially among younger people ${ }^{5}$. Accordingly, the growth of mobile device gaming has been driven in great deal by the availability of these new devices with the abundant supply of free apps and content. The usage of smartphones and tablets share similarities regarding their portable nature and they allow using multiple applications. It is likely that this device use is characterized by excessive frequency (i.e., typically played between daily routine tasks), rather than excessive duration due to its typical usage purpose and the portable nature of the devices. However, this association needs to be clarified through further studies.

The findings of the current study demonstrated that gaming patterns in terms of computer or mobile devices consumption differed among participants according to the game genre preferred. The present findings showed that the casual games (e.g., Candy Crush Saga) were the most favored game type. These social games are widely 


\section{ACCEPTED MANUSCRIPT}

played via different devices (e.g., computers, tablets and smartphones) and social networking sites, which partly explains why portable mediums have been widely adopted for gaming among adolescents ${ }^{59}$. The present outcomes also showed that favoring engagement with game genres such as MMORPG, MOBA, strategymanagement and shooting games showed the strongest positive association with PGB symptoms, which is in line with previously established findings ${ }^{33-35}$ and thus provided support for the set hypothesis (Hypothesis 1). Daily gaming time was also highest among participants who preferred to play game genres of MMORPG, MOBA and shooting. Interestingly, the amount of mobile device (i.e., tablet and mobile or smartphone) use was highest among participants who favored to play shooting games. These findings may reflect a view that individuals with PGB symptoms are likely to prefer to play some of the cluster of online game genres encompassing certain features such as role-playing, shooting, strategy and action ${ }^{60}$.

Interestingly, a variance in PGB symptoms was found between online and offline digital game players. The PGB severity was highest among players who favored playing online or used to play in both online and offline contexts compared to individuals who played exclusively online. These findings of the present study support the assumption that PGB can be related to the both online and offline gaming and there can be different structural features in the context affecting the problem's severity ${ }^{61}$.

The data gathered concerning the gaming medium behavior are novel and gave some insight into potential problematic behavior. However, certain limitations need to be 


\section{ACCEPTED MANUSCRIPT}

taken into account in the current study when interpreting the results. First, as the participants of the study consisted of a non-representative sample of junior high school students and the response rate was somewhat modest $(66.2 \%)$, we have to be cautious when generalizing the study findings. Second, due to the cross-sectional design, any conclusions related to causality are not possible to draw. Third, the data is entirely based on self-reporting, which may cause biases (e.g., short-term memory and social desirability biases) and the participants might either over- or underestimate their true media and gaming activity. It should also be noted that, in this study PGB was analyzed as a continuous form, and according to given cut-off points $^{50}$ the proportion of respondents displaying symptoms of problematic gaming use was relative low $(0.9 \%)$. Fourth, this study concentrated on certain gaming media use only, future studies should thus be carried out including console-based game playing. Time spent on a television and other videos was not included in the data. Finally, there is still a need for experimental studies with objective measures of digital media use and gaming behavior.

\section{CONCLUSIONS}

This study identified certain features of gaming contexts and contents which may relate to problematic gaming behavior. The findings of the present study suggest future research regarding problematic digital gaming of adolescents to also target family structural characteristics. In conclusion, the findings from the present study showed that being male, accumulated gaming time, a blended family structure and displaying a preference for specific game genres (i.e., MMORPG, MOBA, strategy- 


\section{ACCEPTED MANUSCRIPT}

management and shooting) related to the presence of PGB symptoms. The present study also supported the evidence that high engagement in both online and offline gaming increase the risk of PGB. Moreover, increasing options of gaming devices available to digital game players may proliferate the general time spent with screens. With this regard, future studies should also pay attention to dose dependent effects, for qualitative factors that indicating in more detail how adolescents use these devices. However, more studies with longitudinal data and larger representative samples are needed to deepen the understanding of the nature of PGB regarding cross-platform associations. These findings provided knowledge that can be utilized in the prevention of the possible negative consequences of digital gaming.

Disclosure

The authors report no conflicts of interest in this work

Acknowledgements

This study was supported by the European Commission (“Tech Use Disorders”; FP7-PEOPLE-2013-IEF627999) through a grant awarded to Olatz Lopez-Fernandez, under the supervision of Professor Joël Billieux. Zsolt Demetrovics was supported by the Hungarian National Research, Development and Innovation Office (Grant numbers: K109375, K111938).

\section{Informed Consent}

An information letter was provided to the parents or guardians, who then decided (passive consent) whether their child take part to the online survey. Individuals agreed to participate in the study through the information page. 


\section{ACCEPTED MANUSCRIPT}

Research Involving Human Participants

The study procedure was conducted in accordance with the Declaration of Helsinki. 


\section{ACCEPTED MANUSCRIPT}

\section{References}

[1] Chassiakos YLR, Radesky J, Christakis D, Moreno MA, Cross C. (2016). Children and Adolescents and Digital Media. Pediatrics. 2016;138:e20162593.

[2] Digital Economy and Society Index [DESI]; 2015. Available at: https://ec.europa.eu/digital-single-market/en/progress-country. Accessed May 3, 2017.

[3] Internet Society. Global Internet Report 2015. Mobile evolution and development of the internet. 2015. Available at: http://www.internetsociety.org/globalinternetreport/assets/download/IS_web.pdf. Accessed March 17, 2017.

[4] Lenhart A. "Teen, Social Media and Technology Overview 2015". Pew Research $\begin{array}{lll}\text { Center. } & 2015 . & \text { Available }\end{array}$ http://www.pewinternet.org/files/2015/04/PI_TeensandTech_Update2015_0409151. pdf. Accessed March 16, 2017.

[5] Ofcom. Children and parents: Media use and attitudes report 2015. 2015. Available at: http://stakeholders.ofcom.org.uk/market-data-research/other/researchpublications/childrens/children-parents-nov-15/. Accessed March 16, 2017.

[6] Entertainment Software Association [ESA]. Essential facts about the computer and video game industry. 2015. Available at: http://www.theesa.com/wpcontent/uploads/2015/04/ESA-Essential-Facts-2015.pdf. Accessed February 7, 2017. 


\section{ACCEPTED MANUSCRIPT}

[7] Deloitte. Mobile Consumer 2015: The Finnish Perspective. The new world of the mobile is rising. 2015.2 Available at: https://www2.deloitte.com/content/dam/Deloitte/fi/Documents/technology-mediatelecommunications/Deloitte-Global-Mobile-Consumer-Survey-2015-web.pdf. Accessed February 7, 2017.

[8] Mäyrä F, Karvinen J, Ermi L. Pelaajabarometri 2015 Lajityylien suosio [The Finnish Player Barometer 2015]. Tampereen yliopisto. TRIM Research Reports. 2016; 21: 62 .

[9] Przybylski AK. (2014). Electronic gaming and psychosocial adjustment. Pediatrics. 2014;134:716-722.

[10] Przybylski AK, Weinstein N. (2017). A Large-Scale Test of the Goldilocks Hypothesis. Quantifying the Relations Between Digital-Screen Use and the Mental Well-Being of Adolescents. Psychological Science. 2017;28:204-215.

[11] Kuss DJ, Griffiths MD. Internet gaming addiction: A systematic review of empirical research. International Journal of Mental Health and Addiction. 2012;10:278-296.

[12] Demetrovics Z, Király O. Commentary on Baggio et al. (2016): Internet/gaming addiction is more than heavy use over time. Addiction. 2016;111:523-524.

[13] Lopez-Fernandez O, Honrubia-Serrano ML, Baguley T, Griffiths MD. Pathological video game playing in Spanish and British adolescents: towards the 


\section{ACCEPTED MANUSCRIPT}

exploration of Internet Gaming Disorder symptomatology. Computers in Human Behavior. 2014;41:304-312.

[14] American Psychiatric Association. Diagnostic and Statistical Manual of Mental Disorders (5th ed.). Washington, DC. Author. 2013.

[15] Griffiths MD, van Rooij A, Kardefelt-Winther D, Starcevic V, Király O, Pallesen S, Müller K, Dreier M, Carras M, Prause N, King D, Aboujaoude E, Kuss DJ, Pontes H, Lopez-Fernandez O, Nagygyorgy K, Achab S, Billieux J, Quandt T, Carbonell X, Ferguson C, Hoff R, Derevensky J, Haagsma M, Delfabbro P, Coulson M, Hussain Z, Demetrovics Z. (2016). Working towards an international consensus on criteria for assessing Internet Gaming Disorder: A critical commentary on Petry et al. (2014). Addiction. 2016;111:167-175.

[16] Petry NM, Rehbein F, Gentile DA, Lemmens JS, Rumpf HJ, Mößle T, Bischof G, Tao R, Fung DS, Borges G, Auriacombe M, González Ibáñez A, Tam P, O|Brien CP. (2014) An international consensus for assessing internet gaming disorder using the new DSM-5 approach. Addiction 2014;109:1399-406.

[17] Király O, Griffiths MD, Demetrovics Z. Internet gaming disorder and the DSM5: Conceptualization, debates, and controversies. Current Addiction Reports. $2015 ; 2: 254-262$.

[18] Pontes HM. Current practices in the clinical and psychometric assessment of internet gaming disorder in the era of the DSM-5: A mini review of existing assessment tools. Mental Health and Addiction Research, 2016;1:18-19. 


\section{ACCEPTED MANUSCRIPT}

[19] Kaess M, Durkee T, Brunner R, Carli V, Parzer P, Wasserman C, Sarchiapone M, Hoven C, Apter A, Balazs J, Balint M, Bobes J, Cohen R, Cosman D, Cotter P, Fischer G, Floderus B, Iosue M, Haring C, Kahn JP, Musa GJ, Nemes B, Postuvan V, Resch F, Saiz PA, Sisask M, Snir A, Varnik A, Žiberna J, Wasserman D. Pathological internet use among European adolescents: Psychopathology and selfdestructive behaviours. European Child \& Adolescent Psychiatry. 2014;23:10931102.

[20] Scharkow M, Festl R, Quandt T. Longitudinal patterns of problematic computer game use among adolescents and adults-a 2-year panel study. Addiction. 2014;109:1910-1917.

[21] Rehbein F, Kliem S, Baier D, Mößle T, Petry NM. Prevalence of internet gaming disorder in German adolescents: diagnostic contribution of the nine DSM-5 criteria in a state-wide representative sample. Addiction. 2015;110:842-851.

[22] Kuss DJ, Griffiths MD, Binder JF. Internet addiction in students: Prevalence and risk factors. Computers in Human Behavior. 2013;29:959-966.

[23] Müller KW, Beutel ME, Egloff B, Wolfling K. Investigating risk factors for internet gaming disorder: A comparison of patients with addictive gaming, pathological gamblers and healthy controls regarding the big five personality traits. European addiction research. 2014;20:129-136. 


\section{ACCEPTED MANUSCRIPT}

[24] Billieux J, Thorens G, Khazaal Y, Zullino D, Achab S, Van der Linden M. Problematic involvement in online games: A cluster analytic approach. Computers in Human Behavior. 2015;43:242-250.

[25] van Rooij AJ, Kuss DJ, Griffiths MD, Shorter GW, Schoenmakers MT, van de Mheen D. The (co-)occurrence of problematic video gaming, substance use, and psychosocial problems in adolescents. Journal of behavioral addictions. 2014;3:157165.

[26] Müller KW, Janikian M, Dreier M, Wölfling K, Beutel ME, Tzavara C, Richardson C, Tsitsika A. Regular gaming behavior and Internet gaming disorder in European adolescents: results from a cross-national representative survey of prevalence, predictors, and psychopathological correlates. European Child and Adolescent Psychiatry. 2015;24:565-574.

[27] Rikkers W, Lawrence D, Hafekost J, Zubrick SR. Internet use and electronic gaming by children and adolescents with emotional and behavioural problems in Australia - results from the second Child and Adolescent Survey of Mental Health and Wellbeing. BMC Public Health. 2016;16:399.

[28] Jeong EJ, Kim DH, (2011). Social activities, self-efficacy, game attitudes, and game addiction. Cyberpsychology, behavior and social networking. 2011;14: 213-21. 


\section{ACCEPTED MANUSCRIPT}

[29] Wang CW, Chan CL, Mak KK, Ho S.-Y, Wong PWC, Ho RTH. Prevalence and correlates of video and internet gaming addiction among Hong Kong adolescents: a pilot study. The Scientific World Journal. 2014; 874648: 9.

[30] Kim MG, Kim J. Cross-validation of reliability, convergent and discriminant validity for the problematic online game use scale. Computers in Human Behavior. 2010;26:43-56.

[31] Kuss DJ, Louws J, Wiers RW. Online gaming addiction? Motives predict addictive play behavior in massively multiplayer online role-playing games. Cyberpsychology, Behavior, and Social Networking. 2012;15:480-485.

[32] Griffiths MD, Pontes HM. (2014). Internet Addiction Disorder and Internet Gaming Disorder are Not the Same. Journal of Addiction Research and Therapy. 2014;5:e124.

[33] Elliott L, Golub A, Ream G, Dunlap E. Video Game Genre as a Predictor of Problem Use. Cyberpsychology, Behavior, and Social Networking. 2012;15:155-161. [34] Eichenbaum A, Kattner F, Bradford D, Gentile DA, Choo H, Hsueh V, Green S. The Role of Game Genres and the Development of Internet Gaming Disorder in School-Aged Children. Journal of Addictive Behaviors Therapy \& Rehabilitation. $2015 ; 4: 3$. 


\section{ACCEPTED MANUSCRIPT}

[35] Lemmens JS, Hendriks SJ. Addictive Online Games: Examining the Relationship Between Game Genres and Internet Gaming Disorder. Cyberpsychology Behavior and Social Networking. 2016;19:270-6.

[36] Donati MA, Chiesi F, Ammannato G, Primi C. Versatility and addiction in gaming: the number of video-game genres played is associated with pathological gaming in male adolescents. Cyberpsychology, Behavior, and Social Networking. 2015;18:129-32.

[37] Kuss D, Griffiths MD, Karila L, Billieux J. Internet addiction: A systematic review of epidemiological research for the last decade. Current Pharmaceutical Design. 2013;20:4026-4052.

[38] Brunborg GS, Mentzoni RA, Melkevik OR, Torsheim T, Samdal O, Hetland J, Andreassen CS, Palleson S. Gaming addiction, gaming engagement, and psychological health complaints among Norwegian adolescents. Media Psychology. 2013;16:115-128.

[39] Brunborg GS, Mentzoni RA, Frøyland LR. Is video gaming, or video game addiction, associated with depression, academic achievement, heavy episodic drinking, or conduct problems? Journal of Behavioral Addictions. 2014;3:27-32.

[40] Carson V, Hunter S, Kuzik N, Gray CE, Poitras VJ, Chaput J-P, Saunders TJ, Katzmarzyk PT, Okely AD, Gorber SC, Kho ME, Sampson M, Lee H, Tremblay MS. Systematic review of sedentary behaviour and health indicators in school-aged 


\section{ACCEPTED MANUSCRIPT}

children and youth: an update. Applied Physiology, Nutrition, and Metabolism. 2016;41:240-265.

[41] Yu L, Shek DTL. Internet addiction in Hong Kong adolescents: a three-year longitudinal study. Journal of Pediatric \& Adolescent Gynecology. 2013;26:10-17.

[42] Wijndaele K, Duvigneaud N, Matton L, Duquet W, Delecluse C, Thomis M, Philippaerts RM. Sedentary behaviour, physical activity and a continuous metabolic syndrome risk score in adults. European Journal of Clinical Nutrition. 2009;63:421429.

[43] AAP. American Academy of Pediatrics. Children, Adolescents, and the Media. Council on Communications and Media. Pediatrics. 2013;132:958-961.

[44] Australian Government. Make your move - sit less - be active for life. Australia's Physical Activity \& Sedentary Behaviour Guidelines for Children (5-12 years) and young people (13-17 years). Commonwealth of Australia: Department of Health and Ageing. 2012.

[45] American Academy of Pediatrics [AAP]. Council on communications and media. (2016). Media Use in School-Aged Children and Adolescents. Pediatrics. 2016;138:e20162592.

[46] Valkenburg PM, Peter J. Social consequences of the Internet for adolescents. A decade of research. Current Directions in Psychological Science. 2009;18:1-5. 


\section{ACCEPTED MANUSCRIPT}

[47] United Nations Development Programme [UNDP]. Mobiles for human development: 2014 trends and gaps. New York, NY: UNDP. 2014. Available at: http://www.undp.org/content/undp/en/home/librarypage/democratic-

governance/access_to_informationande-governance/mobiles-for-humandevelopment.html_Accessed February 28, 2017.

[48] Tech Use Disorders [TUD]. Technological use disorders: European crosscultural longitudinal and experimental studies for Internet and smartphone problem uses. 2017. Available at: http://cordis.europa.eu/project/rcn/189961_en.html. Accessed June 15, 2017.

[49] Orsmond GI, Kuo H-Y. (2011). The daily lives of adolescents with an autism spectrum disorder: Discretionary time use and activity partners. Autism: The International Journal of Research and Practice. 2011;15:579-599.

[50] Demetrovics Z, Urbán R, Nagygyörgy K, Farkas J, Griffiths MD, Pápay O, Kökönyei G, Felvinczi K, Oláh A. The development of the Problematic Online Gaming Questionnaire (POGQ). PLoS One. 2012;7:e36417.

[51] Brislin EW. Back-translation for cross-cultural research. Journal of CrossCultural Psychology. 1970;1:185-216.

[52] Morera OF, Stokes SM. Coefficient $\alpha$ as a measure of test score reliability: Review of 3 popular misconceptions. American Journal of Public Health. 2016;106(3):458-461. 


\section{ACCEPTED MANUSCRIPT}

[53] Thomas NJ, Martin FH. Video-arcade game, computer game and Internet activities of Australian students: participation habits and prevalence of addiction. Australian Journal of Psychology. 2010;62:59-66.

[54] Wenzel HG, Bakken IJ, Johansson A, Götestam KG, Øren A. Excessive computer game playing among Norwegian adults: self-reported consequences of playing and association with mental health problems. Psychological Reports. 2009; 105:1237-1247.

[55] Billieux J, Van der Linden M, Achab S, Khazaal Y, Paraskevopoulos L, Zullino D, Thorens G. Why do you play World of Warcraft? An in-depth exploration of selfreported motivations to play online and in-game behaviours in the virtual world of Azeroth. Computers in Human Behavior. 2013;29:103-109.

[56] Han DH, Kim SM, Lee YS, Renshaw PF. The effect of family therapy on the changes in the severity of on-line game play and brain activity in adolescents with on-line game addiction. Psychiatry Research. 2012;202:126-131.

[57] Khantzian EJ. The self-medication hypothesis of addictive disorders: focus on heroin and cocaine dependence. The American Journal of Psychiatry. $1985 ; 142: 1259-64$.

[58] Liu C-H, Lin S-H, Pan Y-C, Lin Y-H. Smartphone gaming and frequent use pattern associated with smartphone addiction. Medicine. 2016;95:e4068. 


\section{ACCEPTED MANUSCRIPT}

[59] Griffiths MD. Child and adolescent social gaming: What are the issues of concern? Education for Health. 204;32:19-22.

[60] Nagygyörgy K, Urbán R, Farkas J, Griffiths M, Zilahy D, Kökönyei G, Mervó B, Reindl A, Ágoston C, Kertész A, Harmath E, Oláh A, Demetrovics Z. Typology and socio-demographic characteristics of Massively Multiplayer Online Game players. International Journal of Human-Computer Interaction. 2013;29:192-200

[61] Smohai M, Urbán R, Griffiths MD, Király O, Mirnics Z, Vargha A, Demetrovics Z. Online and offline video game use in adolescents: measurement invariance and problem severity. The American Journal of Drug and Alcohol Abuse. 2017;43:111-116. 


\section{ACCEPTED MANUSCRIPT}

Table 1. Correlations and internal consistencies of the factors in the Finnish POGQ test

\begin{tabular}{|l|l|l|l|l|l|l|l|}
\hline & $\mathbf{1}$ & $\mathbf{2}$ & $\mathbf{3}$ & $\mathbf{4}$ & $\mathbf{5}$ & $\mathbf{6}$ & $\mathbf{7}$ \\
\hline 1. Preoccupation & 1 & - & - & - & - & - & \\
\hline 2. Overuse & .49 & 1 & - & - & - & - & \\
\hline 3. Immersion & .61 & .56 & 1 & - & - & - & \\
\hline 4. Social isolation & .65 & .52 & .60 & 1 & - & - & \\
\hline 5. Interpersonal conflicts & .58 & .61 & .58 & .56 & 1 & - & \\
\hline 6. Withdrawal & .68 & .58 & .67 & .68 & .69 & 1 & \\
\hline 7. Total POGQ scores & .78 & .77 & .85 & .80 & .80 & .88 & 1 \\
\hline Cronbach's $\alpha$ & .66 & .77 & .71 & .78 & .70 & .86 & \\
\hline
\end{tabular}

Note. All correlations were significant at the level of $p<.01$ 
Table 2. Characteristics of the study sample

\begin{tabular}{|c|c|c|c|c|}
\hline \multirow[t]{2}{*}{ Variable } & \multicolumn{2}{|c|}{ Gamers } & \multicolumn{2}{|c|}{ Non-gamers } \\
\hline & $N$ & $\%$ / Mean $(S D)$ & $\mathrm{N}$ & $\% /$ Mean $(S D)$ \\
\hline \multicolumn{5}{|l|}{ Gender } \\
\hline Female & 173 & $37.2 \%$ & 84 & $88.4 \%$ \\
\hline Male $^{\mathrm{a}}$ & 292 & $62.8 \%$ & 11 & $11.6 \%$ \\
\hline \multicolumn{5}{|l|}{ School grade } \\
\hline $7^{\text {th }}$ & 200 & $43 \%$ & 30 & $31.6 \%$ \\
\hline $8^{\text {th }}$ & 114 & $24.5 \%$ & 24 & $25.3 \%$ \\
\hline $9^{\text {th }}$ & 151 & $32.5 \%$ & 41 & $43.2 \%$ \\
\hline \multicolumn{5}{|l|}{ Age } \\
\hline 12 & 20 & 4.3 & 5 & 5.3 \\
\hline 13 & 186 & 40 & 27 & 28.4 \\
\hline 14 & 118 & 25.4 & 27 & 28.4 \\
\hline 15 & 134 & 28.8 & 33 & 34.7 \\
\hline 16 & 7 & 1.5 & 3 & 3.2 \\
\hline \multicolumn{5}{|l|}{ Family structure } \\
\hline Nuclear family & 336 & $72.3 \%$ & 72 & $75.8 \%$ \\
\hline Joint physical custody & 59 & $12.7 \%$ & 7 & $7.4 \%$ \\
\hline Single parent household & 39 & $8.4 \%$ & 12 & $12.6 \%$ \\
\hline Blended family & 22 & $4.7 \%$ & 4 & $4.2 \%$ \\
\hline Other & 9 & $1.9 \%$ & 0 & $0 \%$ \\
\hline \multicolumn{5}{|l|}{ Internet connection at home } \\
\hline$\overline{\text { Yes }}$ & 464 & $99.8 \%$ & 94 & $98.9 \%$ \\
\hline No & 1 & $.2 \%$ & 1 & $1.1 \%$ \\
\hline \multicolumn{5}{|l|}{ Computer ownership ${ }^{b}$} \\
\hline Yes & 319 & $68.6 \%$ & 54 & $56.8 \%$ \\
\hline No & 146 & $31.4 \%$ & 41 & $43.2 \%$ \\
\hline \multicolumn{5}{|l|}{ Tablet ownership } \\
\hline Yes & 247 & $53.1 \%$ & 45 & $47.4 \%$ \\
\hline No & 218 & $46.9 \%$ & 50 & $52.6 \%$ \\
\hline \multicolumn{5}{|l|}{ Cell/smartphone ownership } \\
\hline Cell phone without Internet access & 6 & $1.3 \%$ & 2 & $2.1 \%$ \\
\hline Mobile/smartphone with Internet access & 457 & $98.3 \%$ & 92 & $96.8 \%$ \\
\hline No own mobile/smartphone & 2 & $.4 \%$ & 1 & $1.1 \%$ \\
\hline Average duration spent on a computer on a typical day (minutes) ${ }^{\mathrm{c}}$ & 461 & $72.07(111.33)$ & 95 & $35.75(83.79)$ \\
\hline Average duration spent on a tablet on a typical day (minutes) & 464 & $27.27(65.93)$ & 94 & $24.12(72.78)$ \\
\hline $\begin{array}{l}\text { Average duration spent on mobile/smartphone on a typical day } \\
\text { (minutes) }\end{array}$ & 461 & $\begin{array}{l}123.15 \\
(117.27)\end{array}$ & 93 & $\begin{array}{l}131.85 \\
(111.34)\end{array}$ \\
\hline Average duration spent on digital gaming on a typical day (minutes) & 464 & $74.85(96.71)$ & - & - \\
\hline POGQ Total & 465 & $29.29(10.26)$ & - & - \\
\hline
\end{tabular}

Note.

${ }^{\text {a }}$ A significant difference $\left(\chi_{(1)}^{2}=83.33, p<.001\right)$

${ }^{\mathrm{b}}$ A significant difference $\chi_{(1)}^{2}=4.9, p<.05$

${ }^{\mathrm{c}} \mathrm{A}$ significant difference in computer use time gamers versus non-gamers, $t_{(170)}=3.61, p<.001$ 
Table 3. Average POGQ scores and daily duration spent on gaming, computer, tablet and mobile or smartphone by most-played game genres among adolescents

\begin{tabular}{|c|c|c|c|c|c|c|c|c|}
\hline Gaming genres & Casual & Solo & $\begin{array}{l}\text { Vehicle- } \\
\text { simulati } \\
\text { on }\end{array}$ & $\begin{array}{l}\text { Strategy- } \\
\text { managemen } \\
\mathrm{t}\end{array}$ & Sport & Shooting & MOBA & $\begin{array}{l}\text { MMORP } \\
\text { G }\end{array}$ \\
\hline$N$ & 111 & 24 & 21 & 14 & 60 & 91 & 27 & 18 \\
\hline $\begin{array}{ll}\text { Average } & \text { (Mean, } \\
S D) \text { daily } & \text { gaming } \\
\text { duration }^{\mathrm{a}} & \\
\end{array}$ & $27.8,41$ & $\begin{array}{l}63.9 \\
66.7\end{array}$ & $60,99.9$ & $83.2,71.9$ & $\begin{array}{l}54 \\
39.3\end{array}$ & $\begin{array}{l}134 \\
117.7\end{array}$ & $\begin{array}{l}161.3 \\
114.1\end{array}$ & $96.7,92.5$ \\
\hline $\begin{array}{ll}\text { POGQ } & \text { scores } \\
(\text { Mean, } S D)^{\text {b }}\end{array}$ & $25.8,8.5$ & $\begin{array}{l}33.4 \\
10.4\end{array}$ & $29,6.8$ & $33.9,7.8$ & $\begin{array}{l}26.5 \\
5.9\end{array}$ & $\begin{array}{l}33.7 \\
13.5\end{array}$ & $\begin{array}{l}34.1 \\
11.5\end{array}$ & $35.9,9.4$ \\
\hline $\begin{array}{ll}\begin{array}{l}\text { POGQ } \\
\text { (Median) }\end{array} & \text { scores } \\
\end{array}$ & 24 & 31.5 & 29 & 32.5 & 25.5 & 30.5 & 32 & 36 \\
\hline $\begin{array}{ll}\begin{array}{l}\text { Computer } \\
(M e a n, S D)^{\mathrm{c}}\end{array} & \text { use } \\
(\end{array}$ & $\begin{array}{l}33.6, \\
50.9\end{array}$ & $\begin{array}{l}72.6 \\
102.1\end{array}$ & 57,106 & $73.7,104.3$ & $\begin{array}{l}36.1 \\
50.7\end{array}$ & $\begin{array}{l}121.1 \\
132.8\end{array}$ & $\begin{array}{l}179.2 \\
170\end{array}$ & $87.9,72.5$ \\
\hline $\begin{array}{l}\text { Tablet use (Mean, } \\
\text { SD) }\end{array}$ & $\begin{array}{l}24.5 \\
62.1\end{array}$ & $\begin{array}{l}12.9 \\
18.7\end{array}$ & $\begin{array}{l}16.5 \\
20.2\end{array}$ & $29.8,86.4$ & $\begin{array}{l}22.3 \\
36.9\end{array}$ & $\begin{array}{l}43.6 \\
95.3\end{array}$ & $7.7 / 12.5$ & $16.4,49.5$ \\
\hline $\begin{array}{l}\text { Mobile/smartphon } \\
\text { e use (Mean, } S D)^{\mathrm{d}}\end{array}$ & $\begin{array}{l}129.9 \\
99.9\end{array}$ & $\begin{array}{l}88.1 \\
61.4\end{array}$ & $\begin{array}{l}74.3, \\
59.9\end{array}$ & $127.6,118.8$ & $\begin{array}{l}92, \\
72.1\end{array}$ & $\begin{array}{l}140.3 \\
146.4\end{array}$ & $\begin{array}{l}135.1 \\
175.7\end{array}$ & $\begin{array}{l}108.5 \\
134.2\end{array}$ \\
\hline $\begin{array}{l}\text { Total media use } \\
(\text { Mean, } S D)^{\mathrm{e}}\end{array}$ & $\begin{array}{l}186.9 \\
149.7\end{array}$ & $\begin{array}{l}173.6 \\
124.7\end{array}$ & $\begin{array}{l}147.8, \\
118.9\end{array}$ & $231,153.4$ & $\begin{array}{l}148.9, \\
97.9 \\
\end{array}$ & $\begin{array}{l}298 . \\
255.2\end{array}$ & $\begin{array}{l}322, \\
243.5\end{array}$ & $\begin{array}{l}212.7 \\
190.8\end{array}$ \\
\hline $\begin{array}{l}\text { Proportion } \\
\text { gaming time in } \\
\text { relation to total } \\
\text { media use }(\%)\end{array}$ & 14.8 & 36.8 & 40.5 & 36 & 36.2 & 43.1 & 50 & 45.4 \\
\hline
\end{tabular}

Notes. Kruskal-Wallis test was used to compare the relations between categories

${ }^{\text {a }}$ Post-hoc test significant (i.e. based on mean rank comparison): sport, MMORPG, shooting, MOBA > casual; shooting, MOBA

$>$ vehicle-simulation, sport; MOBA > solo

${ }^{\mathrm{b}}$ Post-hoc test significant (i.e. based on mean rank comparison): shooting, solo, MOBA, strategy-management, MMORPG > casual; shooting, MMORPG > sport

${ }^{\mathrm{c}}$ Post-hoc test significant (i.e. based on mean rank comparison): MMORPG, shooting, MOBA > casual; shooting, MOBA > sport

${ }^{\mathrm{d}}$ Post-hoc test significant (i.e. based on mean rank comparison): casual, shooting > vehicle-simulation; casual > sport

${ }^{\mathrm{e}}$ Post-hoc test significant (i.e. based on mean rank comparison): shooting > vehicle-simulation, casual; shooting, MOBA > sport

${ }^{*}$ Comprised average amount of time used for computer and mobile devices (tablets and mobile or smartphones) per day 


\section{ACCEPTED MANUSCRIPT}

Table 4. Problematic gaming behavior scores regressed for socio-demographics, digital media use and digital gaming characteristics using multiple linear regression analyses

\begin{tabular}{|l|l|l|l|l|}
\hline Predictor & B & SE & Beta & $\boldsymbol{t}$ \\
\hline Intercept & 26.23 & .69 & & $38.01^{* * *}$ \\
\hline The amount of time spent on gaming per day & .048 & .005 & .449 & $9.855^{* * *}$ \\
\hline School grade 9 & -3.618 & .958 & -.172 & $-3.778^{* * *}$ \\
\hline Blended family & 5.581 & 2.344 & .108 & $2.381^{* *}$ \\
\hline MMORPG preference & 5.488 & 2.083 & .120 & $2.635^{* *}$ \\
\hline Solo game preference & 4.949 & 1.820 & .124 & $2.719^{* * *}$ \\
\hline Strategy-management game preference & 5.491 & 2.347 & .107 & $2.340^{*}$ \\
\hline
\end{tabular}

Notes. $\mathrm{R}^{2}=.27(p<.001), \mathrm{B}=$ unstandardized regression coefficient; $\mathrm{SE}=$ standard error; standardized regression coefficient; $t=$ t-test statistic

${ }^{*} p<0.05$

${ }^{* * *} p<0.01$

**** $p<0.001$ 


\section{ACCEPTED MANUSCRIPT}

Figure 1. Average duration used per day (in minutes) for different media within different school grades among gamers and non-gamers

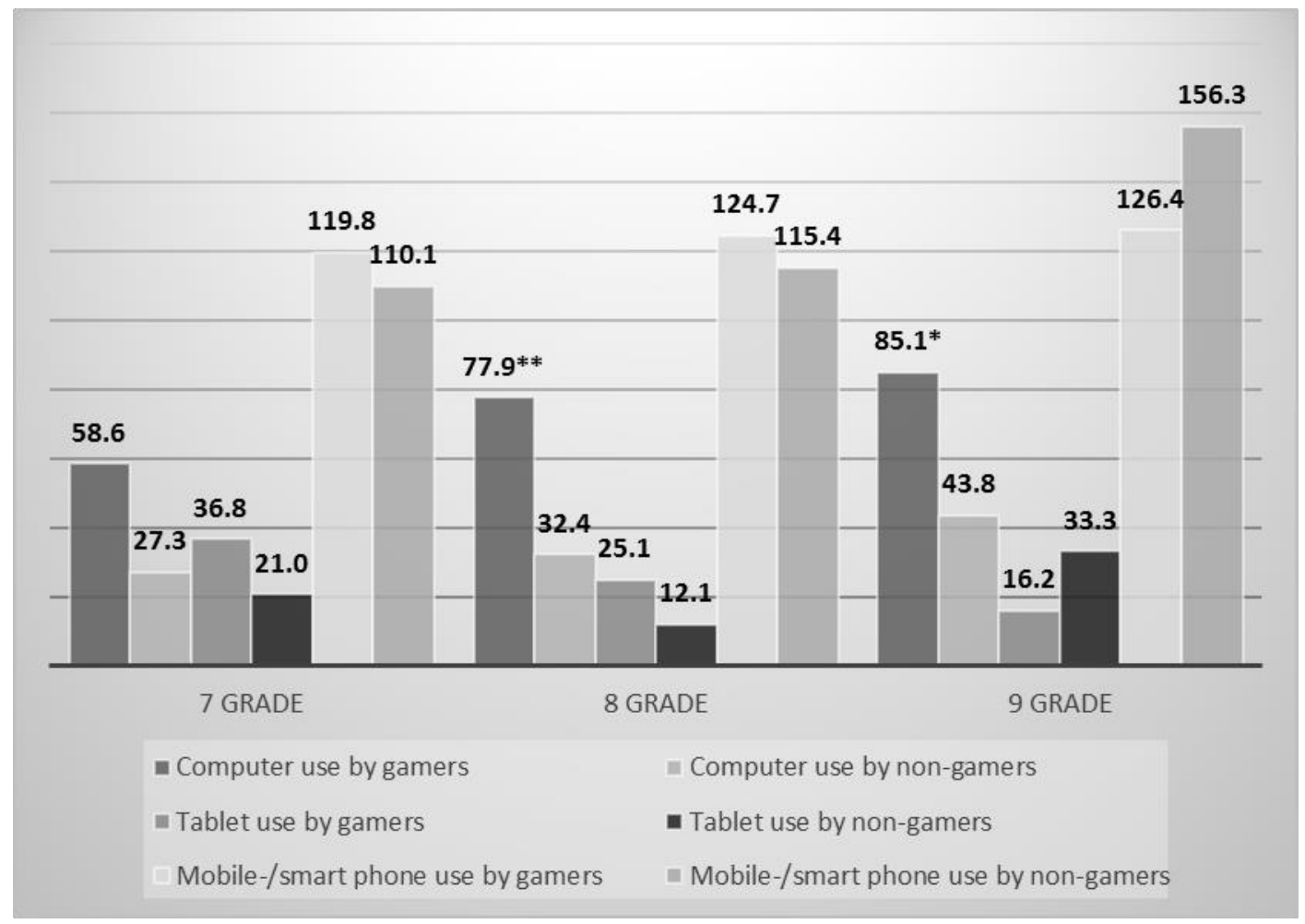

Note. 8 grade: ${ }^{* *}$ A significant difference in computer use time gamers versus non-gamers $t{ }_{(103)}=3.02, p<.01 ; 9$ grade: ${ }^{*} \mathrm{~A}$ significant difference in computer use time gamers versus non-gamers $t_{(73)}=2.14, p<.05$ 